\title{
Action Research: Fostering Students' Oral Production in the EFL Class
}

\author{
Olmedo Bula Villalobos \\ Universidad Estatal a Distancia (UNED) \\ Costa Rica
}

\begin{abstract}
Speaking is a remarkable feature of human beings. People speak on a daily basis in order to communicate and exchange meaningful information. Therefore, the development of such ability in L2 students becomes very important. This study reflects upon the experience of using three speaking activities: 1- a role-play, 2- an interview and 3- speaking workstations to foster students' oral production in the EFL class (English as a Foreign Language). Additionally, the methodology and the action plan are addressed. Facilitated by action research, this study reports on the use and subtleties of these speaking activities. The effectiveness and implementation of these activities are also discussed in this paper. The relevance of these activities to the teaching of speaking constitutes one of the main findings of this paper. Finally, this research project was especially useful as it heightened awareness of the researcher's teaching beliefs.
\end{abstract}

Key words: speaking, oral production, teaching, activities, EFL

\section{Resumen}

El habla es una característica notable de los seres humanos. La gente habla a diario con el fin de comunicarse e intercambiar información significativa. Por lo tanto, el desarrollo de tal habilidad en los estudiantes que están aprendiendo una segunda lengua es muy importante. Este estudio reflexiona sobre la experiencia de usar tres actividades para hablar: 1- un juego de roles, 2- una entrevista y 3- estaciones de trabajo del habla para fomentar la producción oral de los estudiantes en una clase de ILE (Inglés como Lengua Extranjera). Adicionalmente, la metodología y el plan de acción son abordados. Con base en la investigación acción, este estudio informa sobre el uso y las sutilezas de estas actividades para hablar. La efectividad e implementación de estas actividades son también discutidas en este documento. Uno de los principales hallazgos de la investigación lo constituye la relevancia de estas actividades cuando se enseña la habilidad de hablar. Finalmente, este proyecto de investigación fue especialmente útil ya que acentúa la conciencia de las convicciones de enseñanza del investigador.

Palabras claves: hablar, producción oral, enseñanza, actividades, ILE 


\section{Introduction}

"Clerk: Nope, forget it. It ain't happening." "Girlfriend: I think, uh, I'm so gonna call him."

"Politician: There is every likelihood that the meetings are to further détente between the countries." "Waiter: That's no bueno dude!"

$\bigcirc$ peaking is one of the most fundamental and common human behaviors. We speak on a daily basis to communicate and exchange meaningful information. Language teachers must know and understand the subtleties and intricacies of such a skill in order to make informed pedagogical decisions when dealing with speaking. Likewise, speaking is also a very demanding skill for language learners. When speaking, students need to pay special attention to several variables, among others cultural, phonological, social, psychological, linguistic, and physical conditions. In this regard, Bailey (2005) points out: "What we fail to notice on a daily basis, however, are the myriad physical, mental, psychological, social, and cultural factors that must all work together when we speak" (Bailey, 2005, p. 2). Understanding the underlying tenets of speaking is imperative for an environment conducive to learning.

This article studies the experience of using speaking tasks, strategies, and exercise types so as to foster students' oral production in an English as a Foreign Language (hereafter referred to as EFL) environment. Framed within the action research parameters, this article reports on the context of the project, the problem, and the literature review. In addition, the methodology and the action plan are addressed in the paper.
Furthermore, the implementation and observation of the action research are discussed here. Finally, a set of conclusions and implications is also considered.

\section{The Context of the Project}

The purpose of this section is to present the general context of the project. The action research project that I report on here took place at a language center within an EFL context. Based on a communicative approach (CLT), this language center offers a conversational program which consists of ten courses. The courses are taught over periods of four months. This research project focused on two Costa Rican students who are native speakers of Spanish. Both participants are undergraduate university students whose level of English proficiency is intermediate B1 on the CEFR. The students' ages range between 20-25 years. Both students are female and Caucasian. In order to protect the students' identities, they have been given fictitious names. Student number one is referred to as Homo Novus Ivy and student number two as La Princesse Chato. These are significant ideas on the context of the project.

\section{Posing a Problem}

This section contemplates the problem that motivated this action research project. During the first lessons, it was quite evident that these subjects, Homo Novus Ivy and La Princesse Chato, were not performing as well as they might have been during the consolidation stage. Their oral production was significantly circumscribed in terms 
of quality and time. They were not using the expressions, structures, and vocabulary that had been introduced, pre-taught, and rehearsed during the presentation and controlled practice stages. Their utterances were limited. Likewise, different time measurements revealed that the students' oral production was limited to an intermediate level (approximately two minutes). Interestingly, when asked about specific needs, both subjects indicated that they felt a pressing need to improve their oral skills. These are important considerations when posing the problem.

\section{Review of the Literature}

A definition, the main principles, some distinctive elements to consider when teaching speaking, and different exercise types and tasks are addressed in this section.

\section{What is Speaking?}

Speaking is an oral and productive skill (Bailey, 2005). Speaking "consists of producing systematic verbal utterances to convey meaning" (Bailey, 2005, p. 2). Florez (as cited in Bailey, 2005) says that speaking constitutes "an interactive process of constructing meaning that involves producing and receiving and processing information" (Bailey, 2005, p. 2). Furthermore, one has to acknowledge that speaking represents a challenging skill for language learners, especially at the beginning stages of the learning process.

\section{What is Oral Production?}

It is a foregone conclusion that oral production basically accounts for the ability to communicate effectively with others. Bygates (1991) points out that oral production is the ability to produce sentences in different types of situations (Bygates, 1991). Likewise, O'Malley and Valdez say that oral production is the way people share information about things they are familiar with taking into consideration the conversations' context (O'Malley \& Valdez, 1996).

\section{Principles for Teaching Speaking}

Relevant principles for teaching speaking found in the literature reviewed can be summarized as follows (Bailey, 2005):

- Provide something for learners to talk about. It is evident that people talk in order to communicate messages and meaning. This 'something' has to be perceived as useful by students in order for Second Language Acquisition (SLA) to be successful. That is why language teachers must keep in mind learners' needs and reasons to communicate in the target language -interesting, useful, and thoughtprovoking topics shall be provided for learners to talk.

- Create opportunities for students to interact by using groupwork or pairwork. Since communication is one of the main goals in a language class, groupwork and pairwork offer good opportunities to enhance verbal and nonverbal communication. One can say that, depending on the circumstances, pairwork could be more appropriate basically because students get to talk more when in pairs than when in groups. 
- Manipulate physical arrangements to promote speaking. Changing the physical environment to promote speaking not only gives variety and spice to a language class, but also reflects a real and changing world. Several grouping strategies and physical arrangements can promote oral production quite efficiently. The most common seating arrangements are: Round robin, the inside-outside circle, numbered heads together, find someone who, circulation, mix and match, cocktail party, and tango seating.

- Plan speaking tasks that involve negotiation for meaning. It seems that "in the process of negotiating for meaning, the language addressed to learners gets adjusted to their level and becomes comprehensible to them" (Bailey, 2005, p. 96). Significant exercise types that involve negotiation of meaning are information-gap activities in which student A and student B have a very similar sentence. In this type of exercise, one sentence is correct and the other sentence is incorrect. When negotiating meaning to decide which sentence is correct, learners also 'notice the gap' between what they can say and what they want to say.

- Personalize the content of speaking activities whenever possible. A degree of personalization in speaking activities is always important because it is an effective attention getter. Language teachers need to be clever enough to relate the content to students' interests and circumstances. These include their names, favorite sports and teams, jobs, cities, countries, likes and dislikes.
- Encourage learners to take reasonable risks in English. Language teachers need to encourage learners to take reasonable risks in order to promote acquisition and growth experiences. These risks may include somehow informal and less stressing activities like going to a party, attending a conference, and chatting on the computer. Next, language teachers also need to teach students communication strategies to participate effectively on these situations and in more formal settings, for example false repetition questions and the correct intonation of question tags among others.

These principles become relevant when designing and performing a speaking activity.

\section{Important Elements to Consider when Teaching Speaking}

Some significant elements for teaching speaking are addressed in this part of the review. The first element is technology. One important consideration is the one offered by Hanson- Smith and Rilling (2006) when they say that technology in education begins with teachers and ends with teachers. It is true that when language teachers are not that interested in computers or are not literate in the field, their pupils tend not to go to the lab or experience learning through technology. On the other hand, when language teachers use computerassisted language learning (CALL) and other technologies in their lessons to collaborate, learners "flourish in surprising ways" (Hanson-Smith \& Rilling, 2006, p. 2). Next, computer-assisted language learning is promoting a "quiet 
revolution" (Hanson-Smith \& Rilling, 2006 , p. 2) by making positive changes that lead to new ways of learning and teaching, which includes the teaching of speaking. One can also say that these new ways of teaching and learning enhance collaborations among students and teachers and create independence and autonomy. This is leading learners to speak more in a real context and in a meaningful way.

Pronunciation is the second element. Undoubtedly, pronunciation is paramount when teaching speaking. Nevertheless, it is relevant to mention that students and teachers need not worry about pronunciation at the very beginning stages of the learning process (Celce-Murcia, 1987). Additionally, it is also important that the focus of pronunciation instruction centers and deals with communication rather than manipulation of sounds (Celce-Murcia, 1987). Celce- Murcia (1987) points out: "My students have shown me that their pronunciation improves far more from doing these kinds of communicative activities than it ever did while they were doing the old techniques... " (Celce-Murcia, 1987, p. 11). Finally, teaching pronunciation (vowel / consonant discrimination, intonation patterns, linking, deletion rules syncopeth, flap, reduction of function words, word stress rules, prominence, vowel reduction schwa, lengthening, and supra segmentals) makes our students sound more natural, fluent and intelligible, and enables them to participate effectively in interactions.

The third element is students' first language (L1). This is truly an important element to take into account, especially in an EFL context in which students usually share the same na- tive language. Teachers, particularly when working with beginners, have to construct manageable and, at the same time, challenging tasks so learners do not switch to their L1. Sometimes, students' L1 may become an advantage in the class, for instance when learning difficult vocabulary. The teacher might just translate the word and move on. It may not be a good idea to completely ban the use of L1. Given the possible roles that students' L1 could play in the classroom, teachers must decide how to capitalize on this element during the lessons.

Oral communication errors are the fourth element. One can say that oral errors are challenging for teachers and students. First, teachers have to decide if they will correct errors. If so, they also have to decide when and how errors will be corrected. It also depends on the focus of the task; for example if learners are successfully conveying meaning even with some errors, the idea is not to interrupt the learner to correct those errors, as stated within the context of Communicative Language Teaching (CLT). Next, it is always relevant to keep in mind that teachers want their learners to talk; constant correction of errors might discourage them from speaking. Likewise, it is significant "not to treat errors in a punitive fashion or to belittle the students when they are working hard to communicate in a new language" (Bailey, 2005, p. 174). Other factors are also important when dealing with speaking in a language class, for example, age or maturational constraints, aural medium, sociocultural factors, affective factors (Shumin, 2002), reticence, dominance, learning styles, multi-level classes, and large classes (Bailey, 2005). 


\section{Speaking Exercise Types and Tasks}

The purpose of this section is to list the most relevant exercise types and tasks. Bailey (2005) provides the following speaking activities: 1 . conversations, guided conversations, and interviews 2 . information gap and jigsaw activities 3. scripted dialogues, drama, and role-playing 4. logic puzzles 5. picture-based activities 6 . physical actions in speaking lessons, and 7. extemporaneous speaking. Other common speaking exercise types and activities include: 1 . cartoon strip stories 2 . movie reviews 3 . short stories and plays and 4. speaking workstations.

In summary, these are some significant principles, exercise types and tasks, and distinctive elements related to speaking skills that may be used in the EFL classroom in order to provide valid speaking opportunities.

\section{Methodology}

This section provides information on the methodology and the research design that were used. This research project adopted a qualitative descriptive methodology. It is an example of qualitative descriptive research because it looks at, describes, interprets, and analyzes a phenomenon in a detailed way so as to seek a holistic, indepth understanding of the situation and its subtleties. In this regard, Leedy and Ormrod (2010) point out that: “... qualitative approaches... involve studying those phenomena in all their complexity. Qualitative researchers... recognize that the issue they are studying has many dimensions and layers, and so they try to portray the issue in its multifaceted form" (Leedy \& Ormrod, 2010 , p. 135). The goal of qualitative research focuses mainly on providing a set of different interpretations of the phenomenon with the purpose of showing understanding of the problem in the inside. Finally, Burns (1999) states: "The aim of qualitative approaches is to offer descriptions, interpretations and clarifications of naturalistic social contexts... qualitative research draws on the data collected by the researcher to make sense of the human behaviour within the research context" (Burns, 1999, p. 22).

Regarding the research design, action research was chosen because of the concrete possibilities it offers to solve everyday problems within a social context. Its cyclical process provides unique opportunities to implement actions, observe them, and analyze their impact when solving an issue. Action research basically promotes social change with practical actions by transforming the current reality and offering feasible solutions to concerns. Likewise, Burns (1999) points out:

... action research applies a systematic process of investigating practical issues or concerns which arise within a particular social context. This process is undertaken with a view to involving the collaboration of the participants in that context in order to provide evidence that can point to change. In contrast to some other forms of research which seek to test out theoretical ideas and to validate them independently, action research is driven by practical actions from which theories about learning and teaching can be drawn. Action researchers initiate an exploratory and interpretive process in which data in 
and about the social context is documented and collected. This is done so that issues and concerns in that context can be examined in order to enhance the way they are currently addressed. (Burns, 1999, p. 31)
Let us examine figure 1 that exemplifies the cyclical process of this action research design.

These are paramount concepts of the methodology and research design of the project.

Figure 1

The Cyclical Process of Action Research

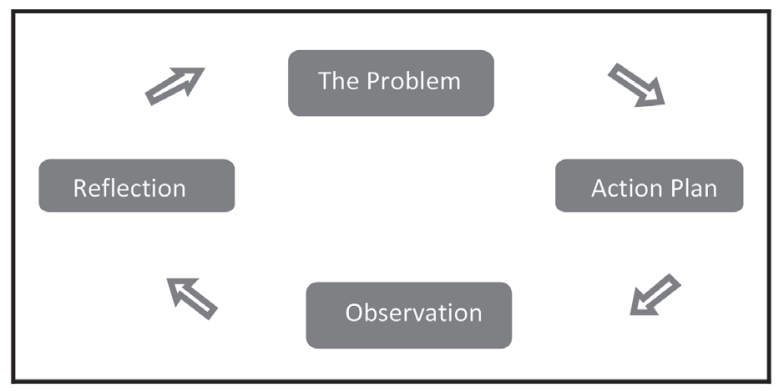

Source: Researcher's design

\section{Action Plan}

In order to foster students' oral production in the EFL class, the following plan of action was designed. First, let us look at the general objectives that guided this action research project. 1 . To conduct action research on speaking activities and tasks so as to promote students' oral production. 2. To foster students' oral production in the EFL class in terms of quality and time. Based on the literature reviewed, I designed a set of speaking activities and tasks to develop fluency and accuracy. These activities can be summarized as follows.

1. Role-play: It is true that roleplays are a significant tool when it comes to rehearsing important elements of vocabulary, grammar, nonverbal skills, and intonation patterns. When defining what a role-play is, Bailey (2005) states that:
A role-play is a speaking activity in which the students take the part of other people and interact using the characteristics of those people (for instance, age, gender, occupation, and so on)... Often a role-play includes a communicative task, such as negotiating a purchase, solving a problem, making a reservation, getting information, and so on. (Bailey, 2005, p. 52)

Likewise, it is paramount for teachers to make sure that the role-play reflects a real-life task.

2. Interview: Interviews are conducted to obtain data. In this regard, Bailey (2005) states: "Interviews are semi-structured sequences of questions intended to elicit particular information from the people answering the questions. Typically one person takes the role of the interviewer and the other person answers the questions" (Bailey, 2005, p. 44). Careful planning 
and design of the interviews prove important to help to build students' confidence and to provide them with sufficient time to go over the questions and possible answers.

3. Speaking workstations: Speaking workstations are truly relevant when fostering students' oral proficiency essentially because pupils develop their critical thinking skills. Speaking workstations contain engaging activities and tasks in which students deepen and rehearse their knowledge on a set of micro and macro skills within a non-threatening environment. Different speaking stations are set up around the class and students move willingly from one station to another according to their needs, wants, and own choosing. Diller (2003) claims that a work station is:

An area within the classroom where students work alone or interact with one another, using instructional materials to explore and expand their literacy. It is a place where a variety of activities reinforce and/or extend learning, often without the assistance of the classroom teacher. It is a time for children to practice reading, writing, speaking, listening, and working with letters and words. (Diller, 2003, p. 2-3)

Predicting is also a significant part of this action plan. It was expected that these students, Homo Novus Ivy and La Princesse Chato, improved and increased their oral production during the consolidation stage in terms of quality and time. Finally, in order to analyse the information in a proper way, I decided to record the interactions of these students during the practice and the consolidation stages as this would be functional for future reference. These are the most relevant features of the action plan.

\section{Implementing and Observing}

This section reviews significant characteristics of the implementation and observation of the action plan. I applied the activities and tasks for each student. It is relevant to mention that students were asked to pair up when working during the practice and the consolidation stages, except for the last activity where they worked in groups. These sessions were stored electronically. Because I had been audio recording the practice and the consolidation stages of our lessons from the outset, not all of which were used for this research project, the students had grown accustomed to having the audio recorder in the class. In addition, I jotted down notes about students' interest and willingness to participate and speak during each task (refer to appendix A to check instrument \#1). Creating a non-threatening environment was of utmost importance so as not to hinder communication or make students feel anxious.

1. Role-play: Students were asked to be as imaginative and inventive as possible when preparing the task. It was quite evident that students felt comfortable when playing the role of another person. During the practice stage, we paid close attention to the useful expressions when rehearsing their usage and form. We reviewed these expressions to check meaning and to encourage students to use them. It is a fact that students were able to construct solid and fluent conversations. Next, a great 
deal of emphasis was given to the difference in meaning between rising and falling intonation. They did use most of the grammatical expressions to convey meaning. Students had no problems whatsoever when formulating the indirect questions. The ready access they had to the expressions was truly vital. Students were constantly checking the handout to use these expressions as required. In terms of intonation, the researcher noticed that students were not producing the rising pattern properly. When students finished presenting their conversation, we basically went over a language focus in order to clarify the correct intonation pattern. With the aid of a student, I modelled the intonation pattern for students to grasp the concept. Likewise, we listened to the conversations that were used in the presentation stage paying close attention to the intonation patterns. Next, students were asked to perform the conversations one more time. It was more than evident that the participants of this project were willing to participate effectively during the conversations. Finally, both students Homo Novus Ivy and La Princesse Chato were asked to perform both roles. For this activity students sat facing each other so as to promote visual contact thus facilitating communication. It took two class periods to finish this activity. The following handout contains the role-play.

\section{Handout \# 1: Role-play \\ Question tags and indirect questions}

Student A: Take the role of a friendly neighbour. You notice that there are new neighbours in town. Establish a conversation. Start the conversation with two question tags (falling intonation). Remember that when your voice falls, it means that you are sure of the answer. You just want to start a conversation (socialization). Then ask two question tags (rising intonation). When your voice rises, it means you are not sure of the answer (real question). Likewise, provide the information your new neighbour needs. Keep the conversation going as long and fluent as possible. Remember to include greetings and farewells.

Some useful expressions

Hi, there!

It's hot, isn't it? ע

Tell me, you work in sales, don't you? $\lambda$

Sure, the bank opens at 10:00 am.

Student B: Take the role of a new neighbour in town. You are just moving in into your new house. One of the neighbours approaches you. Establish a conversation and answer his/her questions. Remember that when the speaker's voice falls in question tags, it means that the speaker is sure of the answer (socialization). When the speaker's voice rises, it means that the speaker is not sure of the answer (real question). Likewise, you need some information about goods and services in the town. Be polite and use indirect questions. Ask as many questions as possible. Keep the conversation going as long and fluent as possible. Remember to include greetings and farewells.

Some useful expressions

Yeah, it's a beautiful day.

No, I am not. I am an industrial engineer.

Do you know if the supermarket opens in the morning?

Can you tell me where the bakery is?

2. Interview: I definitely believe that the time that students devoted to the preparation of the interview was the key for a productive and fluent conversational exchange. Students were asking for very specific details 
and answering with clear ideas. What really caught my attention was the fact that both students were offering thought-provoking arguments when providing their answers. Students demonstrated genuine interest in the activity. My observation notes support this: "In today's class I could really perceive the excitement and willingness as she was trying to vividly describe the things that have been happening in her life. It is obvious that she has an emotional connection with the experience. Rarely have I been this pleased with students' performance." Interviewers were encouraged to take notes to help themselves remember relevant information to ask follow-up questions. Likewise, the perfective aspect of the conversation was emphasized during the preparation and the consolidation stages. Next, students were told to use active listening as a communicative strategy when preparing their interviews (social listening). Finally, both students were asked to take both sides when performing the interview. It took three class periods to finish this task. The following is the handout for the interview.

\section{Handout \# 2: Interview}

Present perfect simple and present perfect progressive

For the interviewer

Begin the interview in a formal way. Good morning. Could I ask you a few questions for...? / Hello. I am working on a project for... May I ask you a few questions?

Pay attention during the interview and carefully listen to the answers.

Use the structures correctly. Have you ever...? / Tell me, what have you been doing...?

Show interest. Really? / Oh / That's quite interesting. / I know what you mean.
Take notes to ask follow-up or clarification questions when necessary.

Jot down important information.

End the interview in a polite way and say thanks.

My notes

For the interviewee

Maintain visual contact.

Be polite and answer the questions in a complete form.

Use the structures correctly. I have never been...

/ I have been studying English...

Make sure to give your opinion. I totally believe that... / If you ask me... / Let us consider... / We need to take into consideration... / It is a fact that...

Answer the questions specifically, truly and undoubtedly.

Be courteous and sophisticated.

3. Speaking workstations: Since we had a big classroom, the four corners of the classroom were used as the stations. Each corner had a poster with a focus on a communicative element that students were to develop. Before students enrolled in the activity, I provided my own comments emphasizing the grammatical structures students were to use. In groups of three to four people, students moved freely from one station to the next to complete the task. At the beginning of the activity, Homo Novus Ivy and La Princesse Chato experienced a small degree of reticence. In order to overcome this situation, I asked a direct question to both students and they started participating naturally in the activity. The more they talked, the more they felt confident with themselves. They felt very motivated when sharing their future plans and long-term 
goals. Next, students were encouraged to ask follow-up questions to get more details and information. Finally, both students participated in the four stations. Two class periods were required to finish this activity. The following handout contains the information for the speaking workstations.

\section{Handout \# 3: Speaking workstations Gerunds and infinitives}

Station 1: Things you are (not) good at Believe it or not, I am really good at listening to... I am not that good at waiting for... basically because...

Station 2: Places you would like (love) to visit and things you would like to do

I'd love to travel to Egypt... It has always been my dream...

I think I would love to buy a house near the...
Station 3: Activities you might do and places you might visit during the summer

I might spend the summer at my parents' house in... Really? I'd rather visit my...

Station 4: Activities you enjoy (love) doing I really love spending time with my grandpa. It's just amazing how we...

I do enjoy pampering myself. When I have an opportunity, I always...

After each speaking activity, a mini feedback session was held to go over significant linguistic features and to analyse strengths and weaknesses.

The following table indicates the amount of time each student spent during each activity. For example, Homo Novus Ivy spent a little less time than La Princesse Chato in the activities. Most notably, a lot of speaking was taking place in the different lessons.

Table 1

Time students spent during speaking activities

\begin{tabular}{cccc}
\hline & Role-play & Interview & Speaking stations \\
Time & Time & Time \\
\hline Homo Novus Ivy & $7 \mathrm{~min}$. & $10 \mathrm{~min}$. & $13 \mathrm{~min}$. \\
La Princesse Chato & $9 \mathrm{~min}$. & $10 \mathrm{~min}$. & $16 \mathrm{~min}$. \\
\hline
\end{tabular}

These were essential elements of the implementation and observation of the action plan.

\section{Reflecting}

The following section considers significant features and facts in the implementation of speaking activities. First, face-to-face interaction is vital for the development of oral production. We must remember that developing speaking skills is a two-way process which involves a speaker (speakers) and a listener (listeners). In the case of the subjects involved, it is certain that both students improved their communication skills, both in quality and time. Second, role-plays, interviews, and speaking workstations are significant face-to-face activities that can develop and foster oral production in the EFL class; for this reason they must be taken into consideration when planning a language lesson. I consider 
them central to the development of oral communication skills; therefore, I reinforce the importance of these activities when teaching speaking. Finally, this action research project was a revealing one in terms of my own teaching style and how action research can actually help students to overcome specific problems. This research project was especially useful as it heightened awareness of my teaching beliefs and professional practice.

Even though students did increase oral production in terms of time and quality, they also made a few errors during the practice basically subjectverb agreement errors. Recast was chosen as a way to raise awareness on the errors. It is important to mention that this technique was only used during the practice stage so as not to interrupt students during the communicative stage. Likewise, it was expected that students would not make the error during the communicative stage.

Instrument \#1 also provided thought-provoking data. Overall, it can be said that students were quite motivated when performing the speaking activities and real-life tasks. Not only were students using the expressions properly, but they were also providing solid arguments during the conversations. It can be concluded that students felt comfortable when performing the tasks, indeed. Although the students made some minor errors, these errors did not hinder successful communication - students were conveying meaning. Based on students' reactions and demeanor, one can say that they did not present any sign of nervousness or anxiety. Finally, students exhibited a proper degree of formality and respect. These are the most relevant characteristics of this section (refer to appendix A to check instrument \#1).

\section{Conclusion}

Finally, the conclusions and considerations discussed in the present paper can be summarized as follows.

The role of students' L1 within an EFL environment and the treatment of oral errors (not mistakes) are related to the teacher's beliefs and viewpoints. One can say that it is imperative that language teachers define in advance the role that students' L1 is going to play in the class. In the same way, teachers need to decide whether they are correcting students' errors or not. If teachers are correcting them, they also need to decide when and how they are going to deal with them. I firmly believe language teachers do not need to interrupt students when performing the communicative tasks (CLT). Instead, I strongly recommend taking notes of the most common errors so as to go over them and take advantage of these learning situations.

Next, it is a must for teachers to go over pronunciation. Pronunciation is a key element. It raises awareness on the different intonation patterns, phonemes, and reduced or blended sounds. It definitely helps students to sound more natural when speaking.

Moreover, it is also the duty of the teacher to create a non-threatening environment where pupils feel safe and confident to express their ideas. Students need to feel that oral errors are not treated in a punitive fashion and that they are a relevant aspect of the learning process. In order to 
effectively create such an environment, teachers must pay close attention to elements like motivation and affective factors. It is my belief that in order to achieve high degrees of motivation among students, the teacher has to take into consideration the following ideas. First, the teacher wants students to 'win'. Students need to experience successful and positive interactions. Next, students need to be provided with comprehensible input (Krashen's i+1). This input has to be comprehensible and, at the same time, it must challenge students to go a step beyond their knowledge by providing new vocabulary and structures (90/10 ratio).

Language teachers must create and design meaningful speaking tasks to foster oral production. Meaningful speaking tasks and exercises usually take the focus off the language and put it on the task performance. Generally students are so engaged in the task that they find ways to convey and negotiate meaning.

Then it is paramount for teachers to base their pedagogical decisions on some basic principles in order to promote students' oral production. One practical way to do this is to create a checklist with the main principles and consider them when designing the speaking task (teachers do not necessarily need to take into account all the principles in one activity).

A further consideration is that if students really want to succeed when participating in oral interactions effectively, they must master learning strategies. Teachers ought to focus on going over successful learning strategies. These techniques include asking for clarification requests, negotiation of meaning, active listening, and false repetition questions.

Later, the students' perception of how and what they are learning represents a truly significant aspect of the process. If students perceive the linguistic elements they are working with as interesting and useful, students become better learners and speakers of the language. It is also true that when performing a speaking activity, students need a thought-provoking topic to talk about.

Raising awareness is absolutely important for students to understand the subtleties of the target language so as to be able to use and recognize relevant linguistic elements.

Furthermore, learning how to speak a foreign language can be very challenging, indeed. It requires learners not only to know the grammatical and semantic rules of the target language, but also to know sociocultural aspects of the language. It can be said that students must develop an 'inner feeling' of the language in order to really master and understand it, and function within the context of the target language. Finally, Shumin (2002) points out:

Speaking is one of the central elements of communication. In EFL teaching, it is an aspect that needs special attention and instruction. In order to provide effective instruction, it is necessary for teachers of EFL to carefully examine the factors, conditions, and components that underlie speaking effectiveness. (Shumin, 2002, p. 210)

It can be concluded that these speaking activities and real-life tasks fostered students' oral production in the EFL class. 


\section{Bibliography}

Bailey, K. (2005). Practical English Language Teaching: Speaking. New York: McGraw Hill.

Bygates, M. (1991). Speaking. United Kingdom: Oxford University Press. Burns, A. (1999). Collaborative Action Research for English Language Teachers. Cambridge: Cambridge University Press.

Celce-Murcia, M. (1987). Teaching Pronunciation as Communication. In J. Morely (ed.), Current Perspectives on Pronunciation (pp. 5-12). TESOL.

Diller, D. (2003). Literacy Work Stations: Making Centers Work. Stenhouse Publishers.

Hanson-Smith, E. \& Rilling, S. (2006). Learning Languages through Technologies. TESOL.

Helgensen, M. \& Brown, S. (2007). Practical English Language Teaching: Listening. New York: McGraw Hill.

Ioannou, S. (2006). The Future of CALL. ELT Journal, 60-4, 382-384.

Krashen, S. (1982). Principles and Practice in Second Language Acquisition. New York: Pergamon Press.

Larsen-Freeman, D. (2000). Techniques and Principles in Language
Teaching. Second Edition. New York: Oxford University Press.

Leedy, P. \& Ormond, J. (2010). Practical Research Planning and Design. Boston: Pearson Education.

Lightbown, P. \& Spada, N. (1999). How Languages are Learned. Second Edition. Oxford University Press.

O'Malley, J. \& Valdez, P. (1996). Authentic Assessment for English Language Learners. USA: Longman.

Richards, J. \& Renandya, W. (2002). Methodology in Language Teaching: An Anthology of Current Practice. New York: Cambridge University Press.

Richards, J. \& Rodgers, T. (2001). Approaches and Methods in Language Teaching. Second edition. New York: Cambridge University Press. Shumin, K. (2002). Factors to Consider: Developing Adult EFL Students Speaking Abilities. In J. Richards \& W. Renandya (eds.), Methodology in Language Teaching (pp. 204211). Cambridge: Cambridge University Press.

Wallace, M. (1998). Action Research for Language Teachers. Cambridge: Cambridge University Press. 


\section{Appendix A}

Instrument \#1

Date:

Student:

\section{Questions}

Did the student show interest when performing the activity?

Was the student willing to participate in the activity?

Did the student use the phrases and expressions properly?

Were the structures grammatically correct?

Was the student anxious or nervous when performing the activity?

Were the student's interventions productive?

Did the student complete the task properly?

Did the student exhibit a proper degree of formality during the task?

Were the student's ideas thought-provoking?

What can be concluded on the outcome of the task? 
